\title{
Linguistic Image of Non-Christian Jews in Early Christian Narratives as a Function of Inter-Group Conflict (Theoretical Background)
}

\author{
Amadeusz Citlak iD https://orcid.org/0000-0001-6550-1891 \\ Institute of Psychology \\ Polish Academy of Sciences \\ e-mail: acitlak@psych.pan.pl
}

\begin{abstract}
This article is an attempt to apply a modern social psychology thesis to reproduce a linguistic image of non-Christian Jews in chosen narratives taken from the Greek canonical Gospels of the New Testament. In the first century AD, non-Christian Jews and primitive Christians found themselves in a state of growing ideological conflict resulting in marked changes in their social relations and mutual perceptions. While remaining in close connection with the usage of language and discourse creation, these changes led to the adoption of new linguistic strategies among primitive Christians, thanks to which the image of non-Christian Jews took on over the course of the following years characteristics of negative stereotypes. A structural model has been used to analyse Christian texts, allowing for consistent and uniform comparisons of available sources. The aim of this paper therefore is an attempt to recreate linguistic characteristics of Jews in primitive Christian documents. There is also an alternative proposal for the analysis of stereotypes against that which has been used for many years in the study of anti-Judaism in historical documents. I will present the theoretical context (a short historical outline) and accepted psychological theories.
\end{abstract}

Keywords: social psychology of religion, Jewish-Christian relations, anti-Judaism, anti-Semitism, stereotype, linguistic image of the world

Słowa kluczowe: społeczna psychologia religii, relacje żydowsko-chrześcijańskie, antyjudaizm, antysemityzm, stereotyp, językowy obraz świata 
The problem of stereotypes in the first Christian documents (especially in the New Testament) has appeared quite often in recent years, especially in the context of anti-Semitism and anti-Judaism. ${ }^{1}$ Some scholars, including some Christian theologians, openly claim that the New Testament texts contain content that can be considered as typical examples of prejudice and stereotypes. ${ }^{2}$ This is a serious problem in contemporary Christian-Jewish dialogue, as well as a problem of the nature of the canonical Christian texts. In the 1970s, Rosemary Radford Ruether wrote that anti-Judaism is the "left hand of Christology" and that "there is no way to rid Christianity of its anti-Judaism, which constantly takes social expression in anti-Semitism, without finally grappling with its Christological hermeneutical self". ${ }^{3}$ A similar thesis can be found in Jules Isaac's and Gregory Baum's books. ${ }^{4}$ This extremely radical position accelerated the contemporary Jewish-Christian critical discussion on the problem of anti-Judaism in early Christian texts. This has also become one of the main problems in the contemporary ecumenical discourse. Biblical scholars discuss different forms of anti-Judaism that are present in the sacred texts (also in the Old Testament), and in the literature there are mentions of, among others, prophetic anti-Judaism, Jewish-Christian anti-Judaism, and gentilizing anti-Judaism. ${ }^{5}$ However, I do not want to consider its differentiation or definitional difficulties.

Scientific analysis of stereotypes and anti-Judaism in the first Christian documents usually takes the form of (more or less) a free commentary on selected passages of the New Testament like Matth. 23; John 8,44; 1 Thess. 2,14-16; Rev. 2,9; 3,9 . Without denying the reliability of such studies, it is important to emphasize that in many cases their authors do not refer to those branches of modern sciences in which the notion of stereotype or prejudice has received significant empirical basis, or where significant conceptual frameworks have been developed, especially in the psychology of inter-group relations and psychology of stereotype/prejudices. I would therefore like to propose an alternative (albeit comprehensive) approach to the study of early Christian literature, firstly referring to structural analysis of texts that will allow for unified comparisons of textual units and secondly, referring to the rich psycholinguistic tradition in which the important characteristics of the language of stereotypes was indicated. This will answer the question of whether we are dealing with anti-Judaistic stereotypes in Greek canonical Gospels, and to what extent.

${ }^{1}$ J. Lamp, Is Paul Anti-Jewish? Testament of Levi 6 in the Interpretation of 1 Thessalonians 2:13-16, "The Catholic Biblical Quarterly" 2003, vol. 65, no. 3, pp. 408-427; J. Siker, Anti-Judaism in the Gospels According to Matthew, Mark, Luke, John, and Mel, "Pastoral Psychology" 2005, vol. 53, no. 4, pp. 303312; P. Toit, The Hermeneutical Dilemma behind 'Anti-Judaism' in the New Testament: An Evangelical Perspective, "The Journal of the South African Theological Seminary" 2015, vol. 20, no. 10, pp. 43-88.

2 T. Donaldson, Jews and Anti-Judaism in the New Testament, Waco 2010; J. Dunn, The Partings of the Ways. Between Christianity and Judaism and their Significance for the Character of Christianity, London 2006.

${ }^{3}$ R. Ruether, Faith and Fratricide: The Theological Roots of Anti-Semitism, New York 1974, p. 116.

${ }^{4}$ G. Baum, Is the New Testament Antisemitic? A Re-evaluation of the New Testament, New York 1965; J. Isaac, Jesus and Israel, New York 1971.

${ }^{5}$ D. Hare, The Rejection of the Jews in the Synoptic Gospels and Acts, [in:] Anti-Semitism and the Foundations of Christianity, A. Davies (ed.), New York 1979, pp. $27-47$. 
Psycholinguistic structural analysis seems to be useful for a fuller understanding not only of the character of the written source but also the mental experience of their authors. This tool allows the collection of data regarding mentality and understanding of how the ancient social world - expressed linguistically at the level of the tex - was understood. I want to show the usefulness of the narrative model based on examples of Greek canonical Gospel texts, and more specifically, on the early Christians' linguistic image of the non-Christian Jews.

\section{Historical Outline}

It is well known that the canonical Gospel texts were created in the second half of the first century AD as the primitive Christians' expression of religious beliefs. This opinion is accepted by most exegetes/Biblical scholars. We know, however, that they were written under conditions of increasing conflict between non-Christian Jews ${ }^{6}$ (followers of traditional Judaism) and the new and growing religious group that were the followers of Jesus ${ }^{7}$ (primitive Christians). For the first ten years after the death of Jesus of Nazareth, the founder of this new religion, mutual misunderstanding and even resentment and hostility systematically grew in strength. Today we know of course that the emergence of Christianity from Judaism was a process and not a oneoff event. ${ }^{8}$ But in the period of interest to us here (the first century AD) one can point to a few events that determine the growing gap between the above-mentioned groups. First, the condemnation and sentencing of Jesus to death by Romans at the beginning of the 30s of the first century AD. Second, the outbreak and fall of the Jewish uprising in 66-70 AD, which accelerated the process of ideological Christian independence. ${ }^{9}$ Third, the negation of the followers of Jesus by the Roman authorities in the person of the Emperor Trajan, which took place shortly after the Synod of Jabne (late 90s), the provisions of which cut off Judaism from everything that was alien to it doctrinally. ${ }^{10}$

Therefore, it can be assumed that as each canonical Gospel was written by primitive Christians, one after the other, the image of non-Christian Jews should have undergone the certain changes. Christians perceived the environment as more and more unfamiliar ideologically while at the same time threatening to their social-religious identity, which was built under conditions of great distress. Mutual conflict and the threat to

\footnotetext{
${ }^{6}$ Non-Christian Jews or orthodox Jews, but orthodox Jews is a modern term, not existing in biblical sources. I will use it as technical term for non-Christian Jews at that time (Pharisees, priests, Sadducees, etc., in the Gospel of John also the Jewish nation as a whole).

${ }^{7}$ In this manuscript I will use sometimes the name Christians in the meaning of followers of Jesus or primitive Christians or Christian Jews in first century AD.

${ }^{8}$ J. Dunn, The Partings of the Ways: Between Christianity and Judaism and their Significance for the Character of Christianity, London 2006; B. Wander, Trennungsprozesse zwischen frühem Christentum und Judentum im I. Jahrhundert n. Chr., Tübingen 1994.

9 S. Brandon, The Fall of Jerusalem and the Christian Church, London 1974.

${ }_{10}$ J. Mayer, Zwischen den Testamenten. Geschichte und Religion in der Zeit des zweiten Tempels, Würzburg 1990.
} 
Christian identity can be interpreted from different theoretical perspectives, although it seems to be particularly helpful in this case to refer to contemporary social psychology and mainstream social cognition. Such theories as Social Identity Theory ${ }^{11}$ or Terror Management Theory ${ }^{12}$ clearly foresee that in cases of conflict (and sometimes even in case of group contact) group members use specific cognitive strategies and thus also linguistic strategies whose aim is to defend the position and status of their own group. One of the techniques used most often is building a negative image of the 'enemy', usually in the form of negative stereotypes, assigning negative characteristics, radicalizing judgments ${ }^{13}$ or increasing the process of dehumanizing the 'outsider'. ${ }^{14}$ Theoretically, all of these linguistic characteristics which represent thoughts about outsiders can be identified at the level of language and text. In practice, however, the task is made all the more difficult in that we hold texts (and this applies not only to ancient sources), which do not always represent the full spectrum of linguistic behavior postulated by psycholinguistics for the given psychological theory. This often depends on the nature of the existing sources. It is not always possible, for example, to analyse the author's personal style if there have been subsequent editorial processes and significant interference in the text, and not every collection of documents written within a given social group makes it possible to see the way a certain social world was understood.

In the analysis presented here, from among the four canonical gospels three have been researched in which Christian authors expressed their attitude toward nonChristian Jews or Jewish society in general, namely in the Gospels of Mark, Matthew, and John. The Gospel of Luke should be taken into consideration together with the Acts of the Apostles as a whole, therefore I resign from it in order not to complicate the planned course of analysis. Avoiding the rather complex discussion of biblical scholars regarding the exact time during which each gospel was written, it can be assumed (in accordance with the majority opinion) that the earliest Gospel was that of Mark, and it was written most likely in the 60s (or 70s) of the first century AD. The Gospel of Matthew was written after the year $70 \mathrm{AD}$ and therefore after the fall of the Jewish uprising. The Gospel of John was edited at the end of the first century AD, or at the turn of the first and second centuries $\mathrm{AD} \cdot{ }^{15}$ It should be added that studying the various gospels does not mean researching the beliefs of one author hidden within

${ }^{11}$ H. Tajfel, Human Groups and Social Categories: Studies in Social Psychology, Cambridge 1981; idem, Social Identity and Intergroup Relations, Cambridge 1982.

12 J. Greenberg, T. Pyszczynski, S. Solomon, The Causes and Consequences of a Need For SelfEsteem: A Terror Management Theory, [in:] Public Self and Private Self, R.E. Baumeister (ed.), New York 1986, pp. 189-212; J. Greenberg, T. Pyszczynski, S. Solomon, D. Lyon, Evidence for Terror Management Theory II: The Effects of Mortality Salience on Reaction to Those Who Threaten or Bolster the Cultural Worldview, "Journal of Personality and Social Psychology" 1990, no. 58, pp. 308-318.

${ }_{13}$ J. Turner, Towards a Cognitive Redefinition of the Social Group, [in:] Social Identity and Intergroup Relations, H. Tajfel (ed.), Cambridge 1992, pp. 15-39. N. Macrae, Ch. Stangor, M. Hewstone, (eds.), Stereotypes and Stereotyping, New York 1999.

${ }^{14}$ Greenberg et al., op. cit.; J. Leyens, Psychological Essentialism and the Differential Attribution of Uniquely Human Emotions to Ingroups and Outgroups, "European Journal of Social Psychology" 2001, no. 31, pp. 395-411.

${ }^{15}$ H. Koester, History and Literature of Early Christianity, Philadelphia 1982; R. Schnackenburg, Zur Herkunft des Johannesevangeliums, „Biblische Zeitschrift” 1970, no. 14, pp. 1-23. 
the text. Modern biblical studies generally recognize that the Gospels are complex documents developed by a few Christian authors within a given period. They express not only the religious beliefs but also the social convictions of early Christians. ${ }^{16}$ In this way, the Gospels reveal not only the Christians' convictions regarding the nonChristian Jews, but when appropriately summarized also demonstrate the evolution of the social beliefs of almost fifty years of increasing antagonism and mutual animosity.

\section{Narrative analysis}

Narrative analysis is currently receiving considerable interest in the humanities. It is used extensively in literary studies, ${ }^{17}$ sociology,${ }^{18}$ psychology, ${ }^{19}$ political science,${ }^{20}$ and even in the philosophy of history. ${ }^{21}$ A special role is played by current research on discourse, however, integrating various ways of analysis and narrative interpretation. $^{22}$ Interest in narratives is high mainly because they relate to a universal way of thinking and organizing human experience regardless of time and place. Narratives make up a story: a kind of structured chronology of history which usually is characterized by a similar structural diagram. This scheme is important both in the narrative unit related to an individual's experience as well as in cultural narratives shared by a larger community expressing supra-individual history or their understanding of the world. The most interesting aspect in this case seems to be, and one often emphasized by psychologists, is that of subjective narrative or, in other terms, its relationship with the author's world of personal experiences, beliefs and emotions. Accordingly, even in historical narratives, objective description of events or recorded facts are not presented but rather seem to be a medium of professed values and attitudes. The psychological perspective of narrative analysis shifts the focus from trying to recreate the facts (historical facts, the actual course of events) to the world of the participants' personal experience of a given culture. In this way, all forms of storytelling, not only as an individual story but also as a great historical work, e.g. The Iliad, The Odyssey, myths, sacred texts, the Gospels, and epistolary literature, ${ }^{23}$ may be the subject of indepth investigation on the grounds of discourse psychology and the psychology of

16 P. Sanders, M. Davies, Studying the Synoptic Gospels, London-Philadelphia 1989.

17 M. Bal, Narratology: Introduction to the Theory of Narrative, Toronto 2002.

${ }^{18}$ L. Griffin, Narrative, Event Structures Analysis, and Causal Interpretation In Historical Sociology, “American Journal of Sociology” 1993, no. 98, pp. 1094-1133.

19 J. Pannebaker, T. Mayne, M. Francis, Linguistic Predictors of Adaptive Bereavement, "Journal of Personality and Social Psychology"1997, no. 72, pp. 863-871.

${ }^{20}$ M. Patterson, K. Monroe, Narrative in Political Science, "Annual Review of Political Science" 1998, no. 1, pp. 315-331.

${ }^{21}$ J. Topolski, Narrative, Reality and Postmodernism: Contributions to the Methodology of the Historical Research, Amsterdam-Atlanta 1994.

${ }^{22}$ T. van Dijk, The Study of Discourse, [in:] Discourse Studies: A Multidisciplinary Introduction, 1, T. van Dijk (ed.), London 1997, pp. 1-34.

${ }^{23}$ H. Hermans, W. van Gilst, Self-narrative and Collective Myth: An Analysis of the Narcissus Story, "Canadian Journal of Behavioral Science" 1991, no. 23, pp. 423-440. 
language. This is all the more so true since language makes up the richest semantical medium, one that can transfer a wealth of information regarding psychological human experiences.

Of great importance to narration scheme analysis methods were the work of Claude Lévi-Strauss and the structural approach to stories of Vladimir Propp. ${ }^{24}$ The presence and impact of such a scheme was often empirically verified, which suggests that it is in fact a universal linguistic method recognized by human experience. I think one of the advantages of a structured approach is a greater objectifying of research and the chance (even partial) to minimize the subjectivity of those representing the humanities, such as philologists and historians.

The narrative scheme is treated as a universal method of organizing events on a timeline. Regardless of the cultural environment, it is characterized by the same construction transmitted to the participants of social life in the processes of socialization. On a deep structural level it includes leading characters (the main character with all their specific features and attributes) driven by a specific motivation and moving towards fulfilling an intended goal. Along the way, the main character meets an antagonist who he or she must overcome. Other key characters are also his or her opponents and supporters with defined characteristics. The surface layer of the narrative, based on the deep layer, directly refers to the subjective worldview of its author. In other words, the universal cultural patterns stored deep in the minds of the authors of the narrative are clothed in senses and meanings already determined situationally or personally. Narrative analysis cultivated by a group can be a rich source of information including, among other things, details regarding linguistic characteristics of revered heroes or condemned dissidents and enemies. Accordingly, when ordered structurally, a cultural narrative presents, simply put, exemplary material suitable for reconstructing the image of selected objects of the social world of the given community or ethnic group. It requires, however, a kind of decoding in accordance with the adopted course of the research investigator.

In the analysis presented, I propose just such a structural decoding of the Gospel narratives which would restore the linguistic representation of the image the early Christians had of the non-Christian Jews. For this purpose, an analysis model has been adopted mainly referring to the findings of Vladimir Propp and in part also to AlgirdasJulien Greimas, ${ }^{25}$ as well as psychological research on the narrative scheme ${ }^{26}$ which takes into account, above all, the subject/event, action and its outcome. The hero of the narrative (with their specified personal characteristics) takes part and is driven by a given motivation (leaving out the detailed characteristics of narrative scheme described in the sources of Propp and Greimas). Characteristics of the hero (in this case, the Jews) are included in my analysis and therefore their description through appropriate verb forms. Next, the characteristics of the hero as expressed through the adjectival forms, as well as the presence of nominal forms as examples of categorization, i.e. what is attributed to the Jews is placed in an appropriate category: moral, religious, or neutral. On

\footnotetext{
24 V. Propp, Morphology of the Folktale, Austin 1968 [1928].

25 A.-J. Greimas, Structural Semantics: An Attempt at a Method, Lincoln 1983 [1966].

26 J. Brunner, The Narrative Construction of Reality, "Critical Inquiry" 1991, no. 18, pp. 1-21.
} 
this basis, it should quite naturally disclose the purpose and motivation of the heroes' actions, i.e. their internal or external and positive or negative motivation and therefore their linguistic and at the same time in-depth hidden psychological image.

Biblical narrative analysis in structural terms is already used widely, and not only in separate monographs or articles but in journals like the "Forum Theologiae Linguisticae". One of the first works using narrative analysis in the interpretation of the Gospel texts was David Rhoads and Donald Michie's work, Mark as Story: An Introduction to the Narrative of a Gospel (1982). Noteworthy is also a work by Robert Scholes and Robert Kellogg, The Nature of Narrative (1966), which analyses selected narratives in ancient literature. Generally, the literature available to us clearly shows the presence of a narrative scheme in biblical discourse, ${ }^{27}$ although such analysis was mostly conducted without reference to psychological problems or without trying to determine the relationship between social cognition and the shape of the narrative itself. ${ }^{28}$

In this consideration, among the many analysed pericopes of the Gospels that describe various episodes from the life of Jesus, such were selected that relate to the Jewish orthodox environment at that time. These are Jesus' dialogues with the scribes, rabbis, crowds listening to him, and his discourse about the priests and Jews which did not believe in him. We do not find a classical structural model in all the narratives as proposed by Propp, among others. Often, we are dealing with a form of religious dialogue between conflicting parties. The Gospels of Mark and Matthew contain pericopes very similar to each other in terms of content. "Matthew" (or better, his editor) often has taken an entire fragment of "Mark" and supplemented or further developed it which, as a total statement, gives material lending to clear comparisons. In contrast, the Gospel of John poses certain difficulties because as a whole it is a kind of settlement with the nation of Israel; the assessment of his attitude toward Jesus of Nazareth and newly founded Christianity. Moreover, the majority of text in the Gospel of John is a unique, individual contribution of this author/editor not found in the other gospels. ${ }^{29}$ Hence the choice of appropriate narrative pericopes from this Gospel are focused on the selection of those that simply reflect attitudes towards Jews, although they do not describe the same events as fragments from Mark or Matthew. Moreover, in contrast to those two previous Gospels, John's narratives are mostly monologues.

For the reasons described above, i.e. the mutual intensifying competition between the two social-religious groups, the formation of the first Christians' identity and the psychological mechanisms resulting from this, it can be expected that the linguistic image of the Jewish worldview in the following gospels will show more and more negative characteristics and consequently take on more negative stereotypes towards

${ }^{27}$ D. Fewell, The Oxford Handbook of Biblical Narrative, Oxford 2016; J. Fokkelman, Reading Biblical Narrative: An Introductory Guide, Westminster 2000; W. Kelber, Gospel Narrative and Critical Theory, "Biblical Theology Bulletin: A Journal of Bible and Theology" 1988, no. 18, pp. 130-136; I. Ramelli, J. Perkins, Early Christian and Jewish Narrative: The Role of Religion in Shaping Narrative Forms, Tübingen 2015.

${ }^{28}$ W. Rollins, Soul and Psyche: The Bible in Psychological Perspective, Minneapolis 1999;W. Rollins, A. Kille, Psychological Insight into the Bible, Grand Rapids-Cambridge 2007.

${ }^{29}$ L. Morris, The Gospel According to John, Grand Rapids 1971. 
the foreign group. The Jews' world should appear as more and more distant from what Christians believed to be right and good, and considering that the Jews rejected the Christians, basic religious values and their ideal of holiness, they naturally would be regarded over time as opponents of sacredness.

In the next part of this consideration I would like to present the most significant and representative examples of the chosen fragments of the Gospels (Mark 11:2712:40; Matthew 21:23-23:29; John 5:30-47; 7:14-36; 8:31-59) ${ }^{30}$ :

Table 1. The basic characteristics of the non-Christian Jews

\begin{tabular}{|c|c|c|}
\hline The Gospel of Mark & The Gospel of Matthew & The Gospel of John \\
\hline $\begin{array}{l}\text { pericope } 1: 11: 27-33: \\
\text { hypocrisy of the scribes }\end{array}$ & $\begin{array}{l}\text { pericope 1: 21:23-27: hypocrisy of the } \\
\text { scribes }\end{array}$ & \multirow{4}{*}{$\begin{array}{l}\text { pericope 1: } 5: 30-47 \text { : } \\
\text { ignorance of the Law of } \\
\text { Moses and the Old Tes- } \\
\text { tament, morality of the } \\
\text { Jews as a denial of the } \\
\text { teachings of Moses and } \\
\text { the prophets }\end{array}$} \\
\hline $\begin{array}{l}\text { pericope } 2: 12: 1-12: \\
\text { disobedience to God, } \\
\text { desire for power }\end{array}$ & $\begin{array}{l}\text { pericope } 2: 21: 28-32^{31}: \text { disobedience to } \\
\text { God, publicans and harlots enter ahead } \\
\text { of the Jews to the kingdom of God }\end{array}$ & \\
\hline $\begin{array}{l}\text { pericope } 3: 12: 13-17: \\
\text { insincerity, the tempta- } \\
\text { tion/trying of Jesus }\end{array}$ & $\begin{array}{l}\text { pericope } 3: 21: 33-46: \text { disobedience to } \\
\text { God, desire for power }\end{array}$ & \\
\hline $\begin{array}{l}\text { pericope } 4: 12: 18-27: \\
\text { ignorance of the Scrip- } \\
\text { tures }\end{array}$ & $\begin{array}{l}\text { pericope } 4: 22: 1-14: \text { 'murderers', un- } \\
\text { worthy of the wedding feast }\end{array}$ & \\
\hline $\begin{array}{l}\text { pericope } 5: 12: 28-34 \text { : } \\
\text { the exception - one scri- } \\
\text { be is close to the king- } \\
\text { dom of God }\end{array}$ & $\begin{array}{l}\text { pericope } 5: 22: 15-22: \text { insincerity, the } \\
\text { temptation/trying of Jesus }\end{array}$ & \multirow[t]{2}{*}{$\begin{array}{l}\text { pericope 2: 7:14-36: The } \\
\text { Jews did not know God, } \\
\text { do not understand the law } \\
\text { of Moses }\end{array}$} \\
\hline $\begin{array}{l}\text { pericope } 6: 12: 35-37: \\
\text { ignorance of the Law of } \\
\text { Moses }\end{array}$ & $\begin{array}{l}\text { pericope 6: 22:23-33: ignorance of the } \\
\text { sacred Scriptures and God }\end{array}$ & \\
\hline \multirow[t]{3}{*}{$\begin{array}{l}\text { pericope } 7: 12: 38-40: \\
\text { warning (against hy- } \\
\text { pocrisy of the Pharisees) }\end{array}$} & $\begin{array}{l}\text { pericope } 7: 22: 34-40: \text { the scribes tempt/ } \\
\text { try Jesus }\end{array}$ & \multirow{3}{*}{$\begin{array}{l}\text { pericope 3: 8:31-59: } \\
\text { Jews as enemies of God } \\
\text { and of Jesus, who want } \\
\text { to kill, do not understand } \\
\text { the Old Testament or the } \\
\text { teachings of Jesus, Jews } \\
\text { are 'children of the devil' } \\
\text { (this applies to the Jews } \\
\text { who believed in Jesus!) }\end{array}$} \\
\hline & $\begin{array}{l}\text { pericope } 8: 22: 41-46: \text { ignorance of the } \\
\text { Scriptures }\end{array}$ & \\
\hline & $\begin{array}{l}\text { pericope 9: 23:1-39: warning: strict, ne- } \\
\text { gative assessment, statement of negative } \\
\text { characteristics of the scribes }\end{array}$ & \\
\hline
\end{tabular}

Source: own work

${ }^{30}$ Each narrative was first placed in a separate table with a breakdown between the various structural elements. Summaries of the basic content of the tables were not included in the text due to high volume. In this article, I focus on the key data from the point of view taken in the analysis. The text source was a critical edition of the Greek text of Erwin Nestle, Kurt Aland, Novum Testamentum Graece (Stuttgart 1993).

31 Italics mark pericopes which are lacking in the Gospel of Mark. 
The text of the Gospel of Mark is clearly shorter than the semantically corresponding text of the Gospel of Matthew. It seems that "Matthew" expanded on topics taken from "Mark", especially those regarding the Jewish environment as personified by the priests, pharisees and scribes. The construction of Matthew's text itself shows an author's tendencies to highlight the negative attitude towards the Jews and moral evaluation of them. "Matthew" additionally includes the parables of "The Two Sons" and "The Wedding Feast" (pericopes 2 and 4), which places the message of the nonChristian Jews on the negative end of the continuum of faithfulness-unfaithfulness towards the Will of God. In the parable of "The Two Sons" the Jews are characterized by their disobedient and unfaithful nature, "[...] the publicans and the harlots go into the kingdom of God before you (Matthew 21:31)." Similarly, in the Parable of The Wedding Feast Israel, as the one invited to the feast, not only is not interested in it but also murders the King's messengers (Matthew 22:5,6). Matthew's narration describes

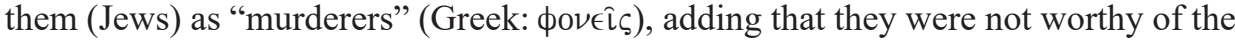
wedding feast (verse 8).

In a dialog found in the Gospel of Mark regarding the two greatest commandments, a scribe calls Jesus "good" and according to Jesus, the scribe himself is not far from the kingdom of God (Mark 12:34). This gives the impression that both parties mutually recognize and relatively accept one another (though it is an exception to the general reluctance of the scribes towards Jesus); however, in the Gospel of Matthew this part of the dialogue with the scribes is no longer present. In the text by "Matthew" Jesus is no longer "good" in the eyes of any of the scribes and there is no scribe who is close the Kingdom of God. A similar change occurs in the Parable of the Wicked Husbandmen (pericope 3): The Gospel of Matthew exposes a much stronger belief that the nation of Israel ignoring Jesus as the Messiah will lose the good entrusted to it and be punished, its place to be taken by others. The editor "places" in the mouths of the Jews the belief and statement about the punishment for disobedience waiting for them ("When the lord therefore of the vineyard cometh, what will he do unto those husbandmen? They say unto him, He will miserably destroy those wicked men and will let out his vineyard unto other husbandmen, which shall render him the fruits in their seasons." Matthew 21:40,41). In the Gospel of Mark, however, these are the words of Jesus as a declaration of future judgment and punishment of the disobedient nation. ${ }^{32}$ In the other words, the Gospel of Matthew makes the Jews aware of their guilt and the punishment which awaits them. However, the most extensive negative narrative passage is the warning against the scribes contained in the Gospel of Matthew chapter 23. It is a catalog of the Pharisees' errors and an unprecedented accumulation of negative evaluations, epithets and even offensive terms $^{33}$ (pericope 9). In the Gospel of Mark it is just a short, one-sentence warning against the scribes (pericope 7). Beyond this, it should be noted that although both Gospels focus on Jesus' talks with the leaders of the nation of Israel, i.e. the priests,

32 "What shall therefore the lord of the vineyard do? He will come and destroy the husbandmen, and will give the vineyard unto others" Mark 12:9.

${ }_{33}$ The warning in the Gospel of Matthew is addressed to the Pharisees and the scribes. In the Gospel of Mark, however, it is only addressed to the scribes. 
Pharisees and scribes, a clearer reference to the Jewish people as a whole appears in the Gospel of Matthew as shown, for example, by adding the Parable of the Wedding Feast (pericope 4) which was to be an invitation to all the people of Israel, not only the priests and the scribes. In a similar way The Gospel of Matthew modifies the narration regarding the Wicked Husbandmen (pericope 3) in such a way that it is evidently about the entire nation of Israel and not just a certain group of people. In the Gospel of Mark 12:9 the householder of the vineyard "gives the vineyard to

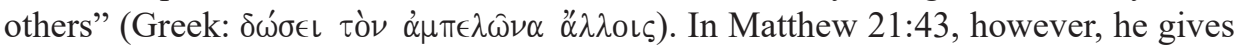

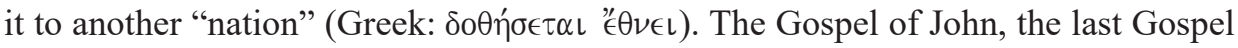
written, presents the Jews from a somewhat different perspective and, although the author/editor does not use such a rich set of negative terms as in the Gospel of Matthew (based on the examples of the dialogues with the Jews), he makes such a deep moral evaluation that basically dispels any illusions and hopes once associated with that nation. The author/editor operates in moral and religious categories such as truth and holiness while at the same time cutting off the Jews from relations with them. The Gospel of John shows not only the Pharisees and priests in a bad light but transfers these assessments to the entire Jewish nation as a whole. Indeed, this is typical of the entire Gospel of John, and the narrative perspectives discussed in the given part of text evidently assumes all Israel as recipients confronted with the person of Jesus expressing the Will of God. Finally, the Gospel of John disqualifies even those Jews

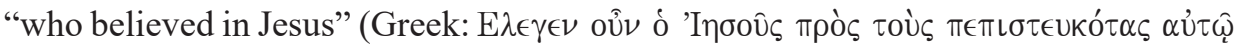
'Iovócíous - 8:31a). ${ }^{34}$

The atmosphere of conflict is indeed evident in all three Gospels (which show the strained relations between the actors and dominant emotions), but the tension between the Jews and Jesus is much more pronounced in the Gospel of John. The third narrative of this Gospel ends with the attempted stoning of Jesus. In the first two Gospels the Jews conspire against Jesus. In John they go into action immediately. One can get the impression that the first Gospel (Mark) showed only the beginning of the conflict between the parties. The second (Matthew) shows its escalation and intensification of hostility while the third (John) a definitive retreat into the opposing camps and lack of expectations for any change. The author of the last Gospel does not even seem surprised by the attitude of the Jews which places them on the side of God's enemies, whose religion is nothing but a failed attempt to hide its true, i.e. evil, sinful nature.

\section{Bibliography}

Bal M., Narratology: Introduction to the Theory of Narrative, Toronto 2002.

Baum G., Is the New Testament Antisemitic? A Re-evaluation of the New Testament, New York 1965 Brandon S., The Fall of Jerusalem and the Christian Church, London 1974.

Brunner B., The Narrative Construction of Reality, "Critical Inquiry" 1991, no. 18, pp. 1-21.

${ }^{34}$ The narrative sequence is preserved, the text editor does not change the recipients who are addressed. 
Donaldson T., Jews and Anti-Judaism in the New Testament, Waco 2010.

Dunn J., The Partings of the Ways: Between Christianity and Judaism and their Significance for the Character of Christianity, London 2006.

Fewell D., The Oxford Handbook of Biblical Narrative, Oxford 2016.

Fokkelman J., Reading Biblical Narrative: An Introductory Guide, Westminster 2000.

Greenberg J., Pyszczynski T., Solomon S., The Causes and Consequences of a Need for Self-Esteem: A Terror Management Theory, [in:] Public Self and Private Self, R.E. Baumeister (ed.), New York 1986, pp. 189-212.

Greenberg J., Pyszczyński T., Solomon S., Lyon D., Evidence for Terror Management Theory II: The Effects of Mortality Salience on Reaction to Those Who Threaten or Bolster the Cultural Worldview, "Journal of Personality and Social Psychology" 1990, no. 58, pp. 308-318.

Greimas A.-J., Structural Semantics: An Attempt at a Method, Lincoln 1983 [1966].

Griffin L., Narrative, Event Structures Analysis, and Causal Interpretation in Historical Sociology, "American Journal of Sociology" 1993, no. 98, pp. 1094-1133.

Hare D., The Rejection of the Jews in the Synoptic Gospels and Acts, [in:] Anti-Semitism and the Foundations of Christianity, A. Davies (ed.), New York 1979, pp. 27-47.

Hermans H., van Gilst W., Self-narrative and Collective Myth: An Analysis of the Narcissus Story, "Canadian Journal of Behavioral Science" 1991, no. 23, pp. 423-440.

Isaac J., Jesus and Israel, New York 1971.

Kelber W., Gospel Narrative and Critical Theory, "Biblical Theology Bulletin: A Journal of Bible and Theology" 1988, no. 18, pp. 130-136.

Kille A., Psychological Dynamics of the Bible in Jewish/Christian Conflict, "Pastoral Psychology" 2005, vol. 53, no. 4, pp. 291-301.

Koester H., History and Literature of Early Christianity, Philadelphia 1982.

Lamp J., Is Paul Anti-Jewish? Testament of Levi 6 in the Interpretation of 1 Thessalonians 2:13-16, "The Catholic Biblical Quarterly" 2003, vol. 65, no. 3, pp. 408-427.

Leyens J., Psychological Essentialism and the Differential Attribution of Uniquely Human Emotions to Ingroups and Outgroups, "European Journal of Social Psychology" 2001, no. 31, pp. 395-411.

Macrae N., Stangor C., Hewstone M. (eds.), Stereotypes and Stereotyping, New York 1999.

Mayer J., Zwischen den Testamenten: Geschichte und Religion in der Zeit des zweiten Tempels, Wurzburg 1990.

Morris L., The Gospel According to John, Grand Rapids 1971.

Novum Testamentum Graece, Nestle E., Aland K. (eds.), Stuttgart 1993.

Pannebaker J., Mayne T., Francis M., Linguistic Predictors of Adaptive Bereavement, "Journal of Personality and Social Psychology" 1997, no. 72, pp. 863-871.

Patterson M., Monroe K., Narrative in Political Science, "Annual Review of Political Science" 1998, no. 1, pp. 315-331.

Propp V., Morphology of the Folktale, Austin 1968 [1928].

Ramelli I., Perkins J., Early Christian and Jewish Narrative: The Role of Religion in Shaping Narrative Forms, Tübingen 2015.

Rollins W., Soul and Psyche: The Bible in Psychological Perspective, Minneapolis 1999.

Rollins W., Kille A., Psychological Insight into the Bible, Grand Rapids-Cambridge 2007.

Ruether R., Faith and Fratricide: The Theological Roots of Anti-Semitism, New York 1974.

Sanders P., Davies M., Studying the Synoptic Gospels, London-Philadelphia 1989.

Schnackenburg R., Zur Herkunft des Johannesevangeliums, „Biblische Zeitschrift” 1970, no. 14, pp. 1-23.

Siker J., Anti-Judaism in the Gospels According to Matthew, Mark, Luke, John, and Mel, "Pastoral Psychology” 2005, vol. 53, no. 4, pp. 303-312.

Tajfel H., Human Groups and Social Categories: Studies in Social Psychology, Cambridge 1981. 
Tajfel H., Social Identity and Intergroup Relations, Cambridge 1982.

Tajfel H., Turner J., An Integrative Theory of Intergroup Conflict, [in:] Psychology of Intergroup Relations, S. Worchel, W. Austin (eds.), Monterey 1979, pp. 33-47.

Toit P., The Hermeneutical Dilemma behind 'Anti-Judaism' in the New Testament: An Evangelical Perspective, "The Journal of the South African Theological Seminary" 2015, vol. 20, no. 10, pp. 43-88.

Topolski J., Narrative, Reality, and Postmodernism: Contributions to the Methodology of the Historical Research, Amsterdam-Atlanta 1994.

Turner J., Towards a Cognitive Redefinition of the Social Group, [in:] H. Tajfel (ed.), Social Identity and Intergroup Relations, Cambridge 1992, pp. 15-39.

Van Dijk T., The Study of Discourse, [in:] T. van Dijk (ed.), Discourse Studies: A Multidisciplinary Introduction, 1, London 1997, pp. 1-34.

Wander B., Trennungsprozesse zwischen frühem Christentum und Judentum im I. Jahrhundert n. Chr., Tübingen 1994. 